\title{
A giant lymphangioma of the body wall in a child: a heavy companion
}

\author{
Harshjeet Singh Bal, Susan Jehangir, Jujju Jacob Kurian
}

Department of Paediatric Surgery, Christian Medical College, Vellore, Tamil Nadu, India

\section{Correspondence to} Dr Harshjeet Singh Bal, balharsh@gmail.com

Accepted 10 November 2014

CrossMark

To cite: Bal HS, Jehangir S,
Kurian JJ. BMJ Case Rep
Published online: [please
include Day Month Year]
doi:10.1136/bcr-2014-
206216

\section{DESCRIPTION}

A 16-month-old boy presented with a painless swelling of the right chest wall that had been progressively increasing since birth. There was no fever or any other associated symptom. He had been initially evaluated at another centre and diagnosed as having lymphangioma, for which he had received intralesional sclerotherapy (details not available); as the swelling did not respond he was brought to our institute. On examination, a non-tender, welldefined large mass involving the right side of the chest and abdominal wall was found. The mass, measuring $40 \times 38 \mathrm{~cm}$, extended from the anterior midline of the body to the right paraspinal region posteriorly and from the right axilla to the right iliac crest vertically (figure 1 ). The ratio of the lesion to the total body length of the child was 0.5 in the vertical dimension. The overlying skin had an area of hyperpigmentation and the mass was soft and fluctuant. There was no swelling elsewhere in the body.

MRI showed a large, well-defined lesion with altered signal intensity involving the soft tissues of the anterior, lateral and posterior chest and abdominal wall on the right side (figure 2). The lesion appeared heterogeneously hyperintense on T2-weighted and isointense with focal hyperintensities on T1-weighted images. There were multiple hypointense intralesional septations of varying thickness present. The lesion was seen to reach up to the ribs of the right lateral chest wall but there was no intrathoracic or intra-abdominal extension. Radiological diagnosis of slow-flow vascular malformation was performed.

The boy underwent injection sclerothreapy using a combination of $3 \%$ sodium tetradecyl sulfate and oxytetracycline. At a 3-month follow-up it was decided to excise the lesion as there was no significant reduction in the size of the mass. He was placed in a left lateral position and a transverse elliptical incision was made at the middle of the mass extending from the lateral border of the right rectus muscle anterior to the lateral border of the latissimus dorsi posterior. The skin flaps were raised and a near complete excision of the lesion was performed. The mass had multiple cysts containing yellowish brown fluid. A thin superficial layer of lesion was left on the skin flaps to protect skin viability. The closure of the subcutaneous tissue and skin was performed over two suction drains. The patient was discharged uneventfully after the operation.

The histopathology report revealed a cystic lymphangioma. On out-patient follow-up on the eighth postoperative day, fluid collection was found to have developed under the skin flaps. This was managed by repeated aspirations and use of injection bleomycin as local sclerotherapy. The child remained well at the last follow-up 4 months postoperatively.

Lymphatic malformations (LMs) consist of fluidfilled cysts derived from lymphatic vessels, which fail to develop connection with the draining venous system. They are considered to be a slow flow vascular malformation and classified as microcystic, macrocystic or combined macrocystic and microcystic lesions. ${ }^{1}$ The term 'lymphangioma' is frequently used for microcytic LMs. The cervicofacial and axillary region are common sites for LMs. ${ }^{2}$ Body wall lymphangiomas are very rare. ${ }^{45}$ The differential diagnosis of such lesions in the paediatric population at this site includes vascular malformations, lipomas, desmoid tumour and malignant soft tissue tumours. ${ }^{6}$ The LMs are usually evident at birth and have progressive enlargement with or without episodic enlargement associated with systemic or localised infection. Clinically, they may present as well-defined localised, ballottable masses or may have extensive tissue involvement. Ultrasound is a useful tool to help initially characterise such mass lesions, however, contrast-enhanced MRI is the most important diagnostic tool as it will show the extent of the lesion and differentiate it from nonvascular and other vascular lesions. ${ }^{1}$ Early diagnosis and complete surgical resection is of utmost importance to avoid morbidity and recurrence of such lesions. Injection sclerotherapy is useful in managing LMs as sole therapy and also as an adjunct to surgical management. ${ }^{2} 37$

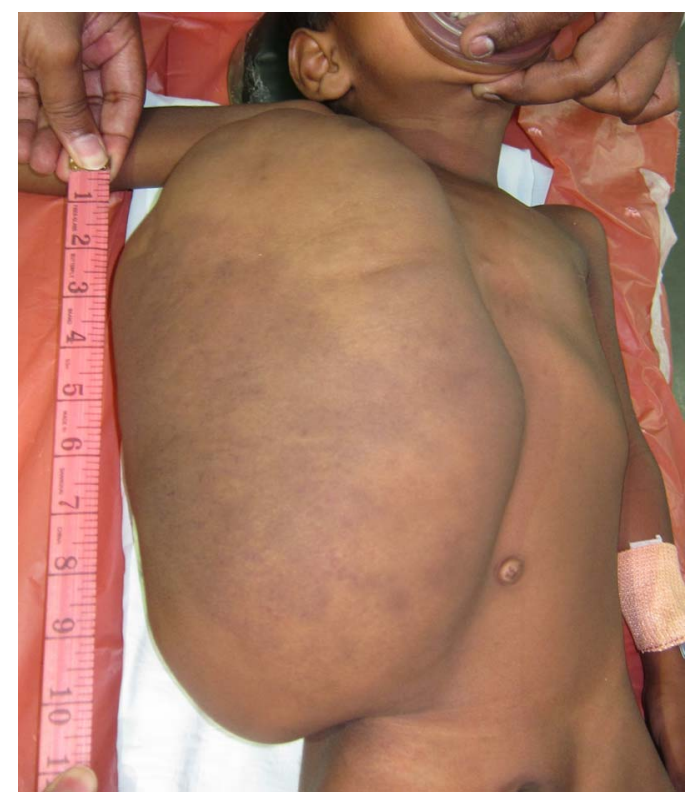

Figure 1 A large right-sided chest and abdominal wall lymphangioma in a child. 
Figure 2 The MRI scan (coronal (A) and transverse (B) section) of the child with right-sided body wall lymphangioma.
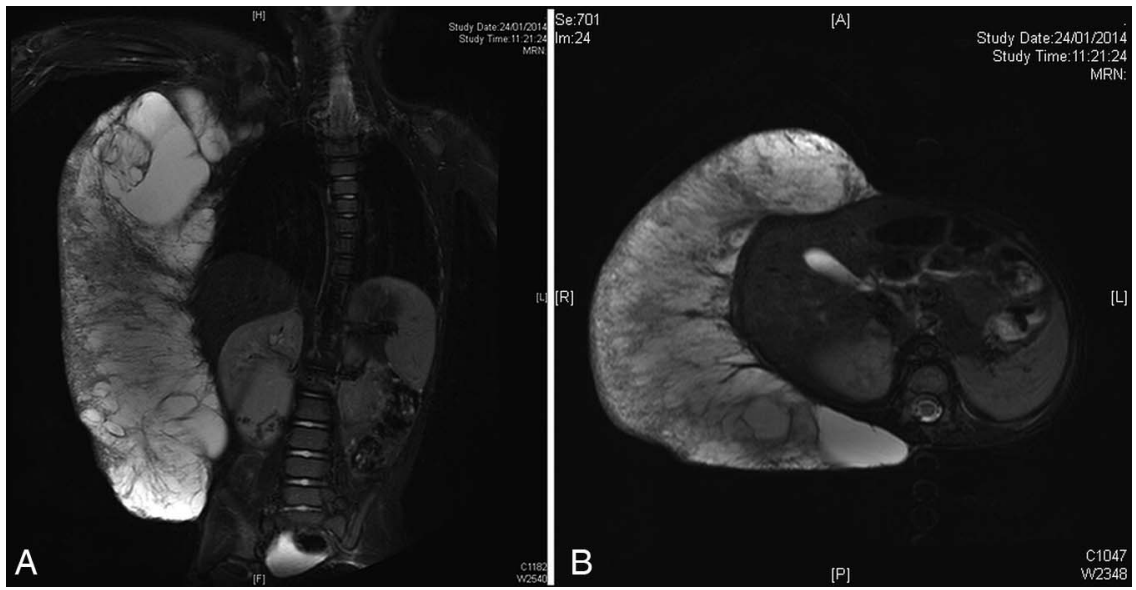

\section{Learning points}

Lymphangioma of the body wall is a very rare condition that can become extremely enlarged if not managed early.

- Early complete resection should be undertaken to avoid massive growth and future recurrence.

- Injection sclerotherapy after surgery is helpful to prevent collection of fluid as well as to prevent recurrence of residual lesions.

\section{Competing interests None.}

Patient consent Obtained.

Provenance and peer review Not commissioned; externally peer reviewed.

\section{REFERENCES}

1 Abernethy LJ. Classification and imaging of vascular malformations in children. Eur Radiol 2003;13:2483-97.

2 Alqahtani A, Nguyen LT, Flageole $\mathrm{H}$, et al. 25 years' experience with lymphangiomas in children. J Pediatr Surg 1999;34:1164-8.

3 Okazaki T, Iwatani S, Yanai T, et al. Treatment of lymphangioma in children: our experience of 128 cases. J Pediatr Surg 2007;42:386-9.

4 Ardenghy M, Miura Y, Kovach R, et al. Cystic hygroma of the chest wall: a rare condition. Ann Plast Surg 1996;37:211-13.

5 Eren S, Avci A. Giant cystic lymphangioma in the thoracic wall in a newborn. Asian Cardiovasc Thorac Ann 2009;17:659.

6 David EA, Marshall MB. Review of chest wall tumors: a diagnostic, therapeutic, and reconstructive challenge. Semin Plast Surg 2011;25:16-24.

7 Kumar V, Kumar P, Pandey A, et al. Intralesional bleomycin in lymphangioma: an effective and safe non-operative modality of treatment. J Cutan Aesthet Surg 2012;5:133-6

Copyright 2014 BMJ Publishing Group. All rights reserved. For permission to reuse any of this content visit

http://group.bmj.com/group/rights-licensing/permissions.

BMJ Case Report Fellows may re-use this article for personal use and teaching without any further permission.

Become a Fellow of BMJ Case Reports today and you can:

- Submit as many cases as you like

- Enjoy fast sympathetic peer review and rapid publication of accepted articles

- Access all the published articles

Re-use any of the published material for personal use and teaching without further permission

For information on Institutional Fellowships contact consortiasales@bmjgroup.com

Visit casereports.bmj.com for more articles like this and to become a Fellow 